\title{
Rural and Central District Primary School Students Body Mass Index and Milk Consumption Habits
}

\author{
Serap Goncu (Corresponding author) \\ Cukurova University, Faculty of Agriculture, \\ Department of Animal Science, Adana, Turkey \\ E-mail:serapgoncu66@gmail.com \\ Bilge Gokce \\ Ministry of National Education, Adana, \\ E-mail: bilgenurgokce@gmail.com \\ Gokhan Gokce \\ Cukurova University, Faculty of Agriculture, \\ Department of Animal Science, Adana, Turkey \\ E-mail: ggokce@cu.edu.tr
}

\begin{abstract}
This study was to planned investigate the milk consumption and body mass index values in rural and central district primary school students. In this context, a questionnaire was applied to 152 children from 59 families, 25 of whom were in the center and 34 living in the countryside, during home visits. In addition, during the survey, the height and weight of the participants were determined and the body mass index values were calculated. The drinking habits of rural and central district students participating in the study were $35 \%$ in the evenings for rural girls and $48 \%$ for boys $(\mathrm{p}=0.211)$; the central region was found to be $55 \%$ in girls and $59 \%$ in boys $(\mathrm{p}=0.282)$. While $20.62 \%$ of the children in the families participating in the survey liked hot milk, $23.5 \%$ liked cold milk, $29.4 \%$ stated that they liked to drink milk with fruit. Although $90 \%$ of the respondents in this study say that they like milk, it is understood that there is irregular milk consumption.
\end{abstract}

Keywords: Milk Consumption, primary school, Students, Habits, body mass index.

DOI: $10.7176 / \mathrm{JSTR} / 7-06-02$

\section{Kırsal ve Merkez İlçe İlköğretim Okulu Öğrencilerinin Vücut Kitle İndeksi ve Süt Tüketim Alışkanlıkları}

\begin{abstract}
Özet
$\mathrm{Bu}$ çalışma, kırsal ve merkez ilçe ilköğretim okulu öğrencilerinde süt tüketimi ve vücut kitle indeksi değerlerinin araştırılması amacıyla planlanmıştır. Bu kapsamda 25'i merkezde, 34'ü kırsalda yaşayan 59 aileden 152 çocuğa ev ziyaretlerinde anket uygulanmıştır. Ayrıca anket sırasında katılımcıların boy ve kiloları belirlenerek vücut kitle indeks değerleri de hesaplanmıştır. Araştırmaya katılan kırsal ve merkez ilçe öğrencilerinin süt içme alışkanlıklarının kırsal bölge kız çocuklarına \%35 erkek çocuklarda $\% 48$ ( $\mathrm{p}=0,211)$; merkez ilçe kız çocuklarında \%55, erkek çocuklarında ise \%59 oranında akşamları süt tüketimi olduğu ( $\mathrm{p}=0,282)$ anlaşılmıştır. Araştırmaya katılan ailelerdeki çocukların \%20,62'si sıcak sütü, \%23,5'i soğuk sütü, \%29,4'ü ise meyveli sütü tercih ettiğini belirtmiştir. Bu çalışmaya katılanların \%90'ı sütü sevdiğini söylese de düzensiz süt tüketimi olduğu anlaşılmıştır.
\end{abstract}

Anahtar Kelimeler: Süt Tüketimi, ilkokul, Öğrenciler, Alışkanlıklar, Vücut kitle İndeksi.

17 | $\mathrm{P}$ a g e

www.iiste.org 


\section{Giriş}

Bir toplumun beslenme kültürü, yaşam şekliyle yakından ilgilidir. Beslenme kültürü, yemek seçimi, tüketim şekli, zamanı ve miktarı ve besinlerin hazırlanması gibi konular yaşanılan toplumun alışkanlıkları ile şekillenir. Eğitim, iletişim, teknoloji ile meydana gelen küreselleşmenin etkileriyle kültürün değişmesi kişilerin beslenme kültürlerine ve tüketim davranışlarına da yansımıştır. Bireylerin yaşam koşullarındaki değişim ve gelişim beslenme kültürünün de değişmesine neden olmaktadır. Son yıllarda köyden şehre göçün artması ile nüfusun büyük kısmı şehirlerde yaşamaya başlamıştır. 2050 yılına gelindiğinde, nüfusun üçte ikisinin şehirlerde yaşayacağı tahmin ediliyor. Türkiye Beslenme ve Sağlık Araştırması-2010 verilerine göre ise ülkemizde 6-18 yaş grubu çocukların \%14,3'ü fazla kilolu, \%8,2'si ise şişman olarak saptanmıştır. Fazla kiloluluk basitçe, vücutta, aşırı ve sağlığı tehdit edecek düzeyde, anormal yağ dokusu artışı olarak tanımlanmaktadır. Fazla kiloluluk Vücut kütle indeksine (VKİ) göre değerlendirilmektedir. VKİ ise vücut ağırlığının yani kilonun, metre cinsinden boy uzunluğuna bölünmesi $\left(\mathrm{kg} / \mathrm{m}^{2}\right)$ ile hesaplanmaktadır. Dünya Sağlık Örgütü yetişkinlerde, VKİ'nin 25-30 arasında olmasını kiloluluk, 30'un üzerinde olmasını ise fazla kilolu olarak tanımlanmaktadır. Vücut kitle indeksi, bireylerin boya göre ideal kiloyu ifade olup yaşa ve cinsiyete bağlı olarak değişmektedir. VKİ, bireyin vücut ağırlı̆̆ının (kg), boy uzunluğunun ( $\mathrm{m}$ cinsinden) karesine $\left(\mathrm{VKI}=\mathrm{kg} / \mathrm{m}^{2}\right.$ ) bölünmesiyle elde edilir. Bu değer Dünya Sağlık Örgütü’nün obezite sınıflandırması esas alınarak obeziteyi belirlemede kullanılmaktadır. VKİ boy uzunluğuna göre vücut ağırlığının tahmininde de kullanılmaktadır. Dünya Sağlık Örgütü referans aralığına göre 18 yaşa kadar, 5-24,99 arası değerler "normal" sayılır. Vücut kitle endeksi değeri 20-25 arasında olanları normal, 25- 30 arasında olanları hafif şişman, 30-35 arasındakileri şişman (obez) olarak tanımlanmaktadır. Çocuk ve adölesanlarda, vücut kitle indeksi tanımlanmasında farklı yaklaşımlar vardır. En sık kullanılan yöntemlerden birisi yüzdelik (persentil) ve z skoru değerlerinin kullanılmasıdır. Çocukluk dönemi doğru, dengeli sağlıklı ve yeterli düzeyde beslenme çocukların sağlık gelişiminde çok önemli yere sahiptir. Çocuk büyümesi, anne karnında başlayıp 21 yaşına kadar değişen düzeylerde devam eden bir süreçtir. Büyüme ve beslenme arasındaki çok yüksek bir ilişki vardır (Neyzi ve ark. 1996; Neyzi ve ark. 2008; Onat ve Ertem, 1995). Beslenme; yaşamın sürdürülmesi, büyüme ve gelişme, sağlığının iyileştirilmesi, korunması ve geliştirilmesi, yaşam kalitesinin iyileştirilmesi, üretkenliğin sağlanması için gerekli olan besin ögelerini sağlayan besinleri tüketerek vücutta kullanılmasıdır (Demirci ve ark. 1992; Maijala 2000). Türkiye Çocukluk Çağı (ilköğretim 2.sınıf öğrencileri) Şişmanlık Araştırması" sonuçları, ilköğretim 2. sınıf çocuklarının yüzde 38'inin her gün, yüzde 31'inin ise haftada 4-6 gün az yağlı ve/veya tam yağlı ile yağlı süt içtiğini göstermektedir. En düşük tüketim 161,7 gram ile Orta Anadolu, en yüksek tüketim ise 227,2 gram ile Güneydoğu Anadolu'da gerçekleştiği bildirilmektedir. TÜİK Hayvansal Üretim İstatistikleri 'ne göre; Türkiye süt üretimi 2019 yılında 23 milyon tondur (TUIK; 2021). Türkiye'de kişi başına ortalama süt tüketimi yıllık 146 litre olup bunun 23 litrelik kısmı içme sütü, geri kalanının ise diğer süt ürünlerinden oluşmaktadır. Yapılan araştırmalarda 1 bardak sütle 6 yaşındaki bir çocuğun günlük ihtiyacı olan B12 vitamininin \%98'inin, fosforun \%55'inin, kalsiyumun \%52'sinin, B12 vitamininin \%44'ünün karşılandığı, özellikle çocukların güçlü kemik yapısına sahip olması için süt tüketiminin çok önemli olduğu belirtilmektedir (Onurlubaş ve Çakırlar, 2016; Anar, 1998). Bu nedenle bu çalışmada kırsal kesim ve il merkezinde yaşayan ilkokul öğrencileri süt ve süt ürünleri tüketim alışkanlıkları ile vücut kitle indeks değerlerinin incelenmesi amaçlanmıştır.

\section{Materyal ve Metot}

$\mathrm{Bu}$ çalışma, kırsal kesim ve merkez ilçe ilkokul öğrencilerinin süt ve süt ürünleri tüketimi ile vücut kitle indekse değerlerini incelemek amacıyla anket çalışması olarak planlanmıştır. Çalışmanın yürütüldüğü Adana ili 35-38' enlemleri ile 34- 46' doğu boylamları arasında yer almaktadır. İlin yüz ölçümü $13.844 \mathrm{~km}^{2}$ 'dir. Adana ili, 2019 yılı verilerine göre 2.258.718 kişi ile en kalabalık altıncı şehri (Çizelge 1) olup ilkokullarda öğretimi sağlanan 168.789’u erkek ve 154.912'si kız olmak üzere toplam 323.701 adet öğrenci eğitim görmektedir. Adana ili nüfusun \% 80'ni şehirlerde yaşmaktadır. Adana nüfusunun yüzde 16,12’1 (351 bin 825 kişi) 15-24 yaşları arasında yer alan genç

18 | $\mathrm{P}$ a g e

www.iiste.org 
nüfustan oluşmaktadır. Adana'nın, 17 ilçesi 46 Belediyesi, 550 köyü bulunmaktadır (Anonim, 2021).

Çizelge 1. Yıllara Göre Adana Nüfusu, yoğunluğu ve artış hızı

\begin{tabular}{|c|c|c|c|}
\hline Yil & Nüfus & $\begin{array}{l}\text { Nüfus yoğunluğu } \\
\left(\mathrm{kişi} / \mathrm{km}^{2}\right)\end{array}$ & Artış Hızı (\%) \\
\hline 2012 & 2.125 .635 & 150 & 0,80 \\
\hline 2013 & 2.149 .260 & 152 & 1,11 \\
\hline 2014 & 2.165 .595 & 153 & 0,76 \\
\hline 2015 & 2.183 .167 & 155 & 0,81 \\
\hline 2016 & 2.201 .670 & 156 & 0,85 \\
\hline 2017 & 2.216 .475 & 157 & 0,67 \\
\hline 2018 & 2.220 .125 & 157 & 0,16 \\
\hline 2019 & 2.237 .940 & 158 & 0,80 \\
\hline 2020 & 2.258 .718 & 160 & 0,93 \\
\hline
\end{tabular}

Yıllara göre değişen Adana Nüfus Yoğunluğuna ek olarak merkez ve kırsal ilçelere göre dağılımı Çizelge 2 de verilmiştir.

Çizelge 2. Adana ili merkez ilçe ve diğer ilçelere ait nüfus bilgileri

\begin{tabular}{|l|c|l|c|}
\hline Merkez İlçeler & \multicolumn{1}{|l|}{ Toplam } & Kursal ilçeler & $\mathbf{1 . 7 7 4 . 5 2 6 ( \% 8 0 )}$ \\
\hline Seyhan & 800.387 & Ceyhan & 160.616 \\
\hline Yüreğir & 424.999 & Kozan & 130.456 \\
\hline Çukurova & 364.118 & İmamoğlu & 28.405 \\
\hline Sarıçam & 163.833 & Karataş & 22.098 \\
\hline Karaisalı & 21.189 & Pozantı & 19.215 \\
\hline & & Yumurtalık & 17.211 \\
\hline & & Tufanbeyli & 16.640 \\
\hline & & Feke & 16.572 \\
\hline & & Aladă & 15.896 \\
\hline & & Saimbeyli & 14.840 \\
\hline Toplam & $\mathbf{1 . 7 7 4 . 5 2 6 ( \% 8 0 . 0 6 )}$ & & $\mathbf{4 4 1 . 9 4 9 ( \% 1 9 . 8 8 )}$ \\
\hline İl toplamı & & $\mathbf{2 . 2 1 6 . 4 7 5}$ & \\
\hline
\end{tabular}

Adana, Toros dağlarının güneyinde bulunan ve Mersin, Osmaniye, Hatay illerini içine alan Çukurova'nın merkezinde, Seyhan nehri üzerinde yer alır. Denizden yüksekliği 23 m. olan Adana da yıllık yağış Adana 734 mm olup en yüksek sıcaklık ortalamasına sahip illerden birisidir. Sıcak koşullar özelikle yaz aylarında süt üretiminde, işlenmesinde ve tüketiminde önemli dalgalanmalara neden olmaktadır (Özkütük ve Göncü, 1996: Göncü Karakök, ve Görgülü 2008. Göncü Karakök ve ark. 2007.).

Aile ve çocuklara ait bilgiler yüz yüze anket ve yerinde gözlem ile araştırıcılar tarafindan tespit edilmiştir. İkincil veriler ise konu ile ilgili daha önce yapılmış çalışmalar ile Türkiye İstatistik Kurumu istatistiki kayıtlarından ve çeşitli sivil toplum örgütlerinin yayınlandığı verilerden elde edilmiştir. Anketin ilk bölümünde, kırsal kesim ve merkez ilçe ilkokul öğrencilerinin ailelerin, boy, kilo ve süt tüketim alışkanlıkları üzerinde durulmuştur. Çocukların boyları metre ile ölçülmüş vücut ağırlıkları ise Hafizalı Akılı Dijital Tartı (Tefal BM2520V0) ile yapılmış̧ır. Çocukların boy kilo endeksi hesaplamasında boy-kilo oranı kullanılmış olup Dünya Sağlık Örgütü’nün obezite sınıflandırmasında

19 | P a g e

www.iiste.org 
aşağıda verilen Vücut Kitle İndeksi-VKİ (Body Mass Index-BMI) formülü kullanılmıştır.

$\mathrm{VKİ}=\mathrm{Ağıll} 1 \mathrm{k}(\mathrm{Kg}) /$ boy $\left(\mathrm{m}^{2}\right)$

Bu kapsamda ev ziyaretlerinde merkezde 25 olmak üzere ile kırsal kesimde 34 yaşayan toplam 59 aile 152 çocuğa anket uygulaması yapılmıştır. Ayrıca anket sırasında çocukların boy ve kilo tespitleri yapılarak Vücut kitle indeksi aşağıdaki formül kullanılarak hesaplanmıştır.

VKİ = Ağırlık (Kg) / boyun metre cinsinden karesi (WHO, 2006).

Bu kapsamda 59 aile ziyaretleri yapılarak 152 çocuğa ait veri elde edilmiştir. Araştrrmada elde edilen veriler, IBM SPSS STATISTIC (SPSS, 2004) ve Excel programı kullanılarak değerlendirilmiştir.

\section{Tartışma}

Araştırmaya katılan ailelerdeki anne ve babaların eğitim durumları dağılımını gösteren Çizelge 3 'e bakıldığında babaların \%29,4'nun eğitimi olmadığı \%32,4'ninde ilkokul mezunu iken annelerin \%55,9'nun eğitimi olmadığı \%29,4'nun da ilkokul mezunu olduğu anlaşılmaktadır.

Çizelge 3. Araştırmaya katılan ebeveyn bilgileri

\begin{tabular}{|l|c|c|c|c|}
\hline Bölge & \multicolumn{2}{|c|}{ Kirs } & \multicolumn{2}{c|}{ Merkez } \\
\hline Ebeveyn & Baba & Anne & Baba & Anne \\
\hline Ebeveyn yaşı (yıl) & $36,06 \pm 1,03$ & $33,00 \pm 0,89$ & $39,03 \pm 0,072$ & $31,02 \pm 0,63$ \\
\hline Çalı̧̧ma oranı (\%) & 29,41 & 17,60 & 80,28 & 70,35 \\
\hline Eğitimli ebeveyn oranı (\%) & 70,59 & 44,10 & 96,00 & 88,00 \\
\hline 3.000 Tl üzeri (\%) gelir & \multicolumn{3}{|c|}{30,00} & \multicolumn{2}{c|}{90,00} \\
\hline
\end{tabular}

Araştırmaya katılanların bölgelere göre ebeveyn yaş ortalamalarına bakıldı̆̆ında babaların kırsal ve merkez için $36,06 \pm 1,033$ ve $39,03 \pm 0,072$; annelerin ise yine aynı sira ile $33,00 \pm 0,89$ ve $31,02 \pm 0,63$

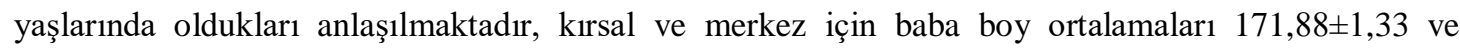
$179,28 \pm 0,63 \mathrm{~cm}$ iken anne boy ortalamalar $160,74 \pm 1,03 \quad 163,24 \pm 1,03 \mathrm{~cm}$ civarındadır. Ankete katılanların eğitim durumları dağılımına bakıldığında Kırsal bölge ebeveynlerinden lise ve üzeri eğitimi olanların oranının \%20,65 iken merkez ilçede bu oranın \%76,00 ya ulaştığı anlaşılmaktadır. Yine ebeveyn çalışma durumlarına bakıldığında kırsal bölgede yaşayanların genel olarak düzenli bir işi olmadığı ancak merkez ilçede yaşayan ebeveynlerin hem çalışan anne - baba oranı yüksektir.

Çizelge 4. Araştırmaya katılan ebeveynlere ait kilo boy ve VKİ değerleri

\begin{tabular}{|l|c|c|c|c|}
\hline Bölge & \multicolumn{2}{|c|}{ Kursal } & \multicolumn{2}{c|}{ Merkez } \\
\hline \multicolumn{1}{|c|}{ Ebeveyn } & Baba & Anne & Baba & Anne \\
\hline kilo $(\mathrm{kg})$ & $78,12 \pm 1,86$ & $68,79 \pm 2,37$ & $82,19 \pm 0,82$ & $62,17 \pm 3,07$ \\
\hline boy $(\mathrm{cm})$ & $171,88 \pm 1,33$ & $160,74 \pm 1,03$ & $179,28 \pm 0,63$ & $163,24 \pm 1,03$ \\
\hline VKİ $(\mathrm{kg} / \mathrm{m} 2)$ & 26,7 & 26,6 & 28,7 & 23,3 \\
\hline
\end{tabular}


Dünya Sağlık Örgütü referans aralığına göre VKI’I 18,5-24,99 arası değerler "normal” kabul edilmektedir. Anket yapılan kırsal bölgedeki ebeveynlerin Vücut Kitle İndeksi değeri 25 'in üzeri olduğu için fazla kilolu, merkez ilçede ise sadece babaların 25 VKI değeri üzerinde olduğu fazla kilolu grupta yer aldıkları anlaşılmaktadır. Araştırma kapsamındaki öğrenciler 6-8 yaş grubunda olup, $\% 54,2$ 'si kız, \%6,8'i erkektir. Araştırmaya katılan kırsal ve merkez ilce öğrenci, yaş, cinsiyet boy ve kilo ortalamaları durumu Çizelge 3 de verilmiştir.

Ortalama ağırlık kızlarda $22 \mathrm{~kg}$., erkeklerde $26 \mathrm{~kg}$ (p=0,873); ortalama boy uzunlukları kılarda 114,5 $\mathrm{cm}$., erkeklerde $118,5 \mathrm{~cm}$ olarak bulunmuştur $(\mathrm{p}=0,132)$. Kızlarda; kentsel bölgede ağırlık ortalamas 1 $20,50 \mathrm{~kg}$ ve kırsal bölgede $24,00 \mathrm{~kg}$ ( $\mathrm{p}=0,123)$; kentsel bölgede boy ortalamas $108,25 \mathrm{~cm}$ ve kirsal bölgede 113,63 ( $\mathrm{p}=0,216)$ olarak saptanmıştır. Erkeklerde; kentsel bölgede ağırlık ortalaması 26,72 kg ve kırsal bölgede $25,45 \mathrm{~kg}(\mathrm{p}=0,631)$; kentsel bölgede boy ortalaması 121,45 cm ve kırsal bölgede $116,45 \mathrm{~cm}(\mathrm{p}=0,152)$ olarak saptanmıştır. Neyzi ve ark.(1978), Kuczmarski ve ark. (2000), Ogden ve ark. (2000) ve Neyzi ve ark.(2008)'nın 20,7 kilo değerinden fazla ama $116 \mathrm{~cm}$ boy uzunluğundan kısa olduğu anlaşılmaktadır. Ancak çalışmalarda yaş sınırlarının 6-8 yaş arası olması varyasyonu artırmaktadır. Vücut kitle indeksi beslenme durumunu değerlendirmede kullanılan ölçütlerdendir (Sarria ve ark. 2001). VKİ değeri çok kolay hesaplanabilir bir formül olup, bütün vücut ve derialtı yağ dokusu ile doğrudan ilişki gösterir. Bununla birlikte VKİ her iki cinsiyet arasında (özellikle de çocukluk döneminde) normal bir dağılım göstermez. Bu nedenle VKİlerini gösteren persentil eğrileri yaygın şekilde kullanılmaktadır. Vücutta toplanan ve VKİ ile yakın ilişki gösteren yağ kitlesi birçok faktörden (cinsiyet, genetik, etnik yapı gibi) etkilenebilir. VKİ için kullanılan referans değerleri ülkeler arasında farklılıklar gösterdiği gibi bir ülkenin farklı bölgelerinde, hatta aynı bölgede yaşayan değişik 1rklarda bile farklılıklar göstermektedir (He ve ark. 2000; Cole ve ark. 1990; Hammer ve ark. 1991). Bu nedenle VKI ile beslenme durumu değerlendirilirken çocuğun yaşadığı bölge için belirlenen standart VKİ persentillerine göre değerlendirilmesi gerekir (Hammer ve ark. 1991). Ülkemizde ise bu konuda çalışmalar (Ayçiçek, 2005; Karakaş ve ark. 2002) olmakla birlikte bölgemiz çocukları için geliştirilmiş standart değerleri gösterir çalışmalar oldukça sınırlı sayıdadır.

Çizelge 5 Araştırmaya katılan kırsal ve merkez ilce öğrenci, yaş, cinsiyet boy ve kilo ortalamaları durumu

\begin{tabular}{|l|c|c|c|c|}
\hline Bölge & \multicolumn{2}{|c|}{ Kirsal } & \multicolumn{2}{c|}{ Merkez } \\
\hline & K1z & Erkek & K1z & Erkek \\
\hline Kilo $(\mathrm{kg})$ & $24,00 \pm 1,36$ & $25,45 \pm 2,18$ & $20,50 \pm 1,55$ & $26,72 \pm 2,08$ \\
\hline Boy $(\mathrm{cm})$ & $113,63 \pm 2,56$ & $116,45 \pm 2,52$ & $108,25 \pm 3,11$ & $121,45 \pm 2,04$ \\
\hline VKİ $\left(\mathrm{kg} / \mathrm{m}^{2}\right)$ & 18,8 & 18,6 & 17,1 & 17,8 \\
\hline
\end{tabular}

Ortalama VKI değeri kırsal bölge kızlarda $18,8 \mathrm{~kg} / \mathrm{m}^{2}$, erkeklerde $18,6 \mathrm{~kg} / \mathrm{m}^{2}(\mathrm{p}=0,131)$; merkez bölge kızlarda $17,1 \mathrm{~kg} / \mathrm{m}^{2}$ ve erkeklerde ise ortalama $17,8 \mathrm{~kg} / \mathrm{m} 2$ olarak bulunmuştur $(\mathrm{p}=0,328) .7$ yaş grubunda obezite sınırı kız çocuklar için 18,09, erkek çocuklar için 18,72'dir. Dünya Sağlık Örgütü referans aralığına göre 18,5-24,99 arası değerler "normal" sayılır. Vücut kitle endeksi değeri 25'in üzeri fazla kilolu, 30'un üzeri obezite, 40'ın üzeri aşırı obez kabul edilir (WHO, 2006: Rosner ve ark. 1998). Boya göre ağırlık değerlendirmelerinde kırsal çocuklarının yaşlarına göre fazla kilolu ve merkez ilçede yaşayan çocukların ise yaş grupları içinde normal kiloda oldukları anlaşılmaktadır. Vücut kitle indeksi ortalamaları yaşla birlikte artış göstermekte ve erkeklerde kızlara göre biraz daha yüksek olduğu bildirilmektedir. Ancak Karakaş ve ark. (2002) yaşla birlikte artış görüldüğünü ancak kızlarda biraz daha yüksek olduğunu bildirmektedir. Karakaş ve ark. (2002) Aydın ili kentsel ve kursal bölge ilköğretim okulları 7-14 yaş grubu öğrencilerinin beden kitle indeksi değerlerini kızlarda.17,12 $\pm 3,16$ $\mathrm{kg} / \mathrm{m}^{2}$ ve erkeklerde $16,86 \pm 2,96 \mathrm{~kg} / \mathrm{m}^{2}$ ve gruplar arası farkı istatistiki olarak önemsiz olduğunu bildirmektedir.

21 I $P$ a g e

www.iiste.org 
Türkiye genelinde çocukların \%70,0'inin normal kiloda, diğerlerinin ise değişen düzeylerde kilo sorunu yaşadığı bildirilmektedir (Anonim, 2011). Araştırmaya katılan ailelerdeki annelerin \%61,8'1, babaların \%67,6 ve çocukların ise 94,1'i sütü sevdiklerini ifade etmişlerdir. Buna göre, çocukların \%35,29 sabahları, \%17,65'si akşamları süt içtiğini belirtirken, diğer zamanlarda ve düzensiz olarak süt tükettiğini bildirmektedir. Süt ve süt ürünlerine özellikle kalsiyum ve fosfor başta olmak üzere bazı önemli mineraller, protein ve riboflavin gibi bazı B grubu vitaminlerin kaynağı olarak bakıldığında önemi anlaşılmaktadır. Süt proteinlerinin büyümeye katkısı, doku farklılaşmalarındaki etkinliğinin yanı sıra; kalsiyum emilimi ve bağışıklık üzerine etkileri olduğu ve ayrıca diş sağlığını koruyucu etkisi bu yaş grubu çocuklarda çok daha öne çıkmaktadır. Ankete katılan ailelerdeki çocukların\%20,62'sı sıcak $\% 23,5$ 'u ise soğuk süt severken \%29,4'u meyveli süt içmeyi sevdiklerini belirtmişlerdir. Araştırmaya katılan kırsal ve merkez ilce öğrencileri süt içme alışkanlıkları kırsal bölge kızlarda akşamları \%35, erkeklerde \%48 ( $\mathrm{p}=0,211)$; merkez bölge kızlarda \%55 ve erkeklerde ise ortalama \%59 olarak tespit edilmiştir $(p=0,282)$. Ülkemizde genel olarak süt içme alışkanlığının halen düşük olduğu ve kırsal ve merkez ilçelerde de benzer durumun geçerli olduğu sonuçlardan anlaşılmaktadır.

Çizelge 6. Araştırmaya katılan kırsal ve merkez ilce öğrencileri süt içme alışkanlıkları

\begin{tabular}{|l|c|c|c|c|}
\hline \multirow{2}{*}{ Bölge } & \multicolumn{2}{|c|}{ Kirsal } & \multicolumn{2}{c|}{ Merkez } \\
\cline { 2 - 5 } & K1z & Erkek & K1z & Erkek \\
\hline Akşamlar1 & 35 & 48 & 55 & 59 \\
\hline Sabah & 20 & 17 & 25 & 26 \\
\hline Diğer & 45 & 35 & 20 & 15 \\
\hline
\end{tabular}

Türkiye Çocukluk Çağı (ilköğretim 2.sınıf öğrencileri) Şişmanlık Araştırması" sonuçları, ilköğretim 2. sınıf çocuklarının yüzde 38'inin her gün, yüzde 31'inin ise haftada 4-6 gün az yağlı ve/veya tam yağlı ile yağlı süt içtiğini ortaya koydu. Araştırmaya göre, kişi başı süt tüketimi günlük 34,5 mililitre, yıllık 12,5 litre, kişi baş1 yoğurt tüketimi ise günlük 112,7 gram, yıllık ise 41,1 kilogram oldu. Kişi baş1 peynir tüketiminin de günlük 39 gram, yıllık 14,2 kilogram olduğu bildirilmektedir.

\section{Sonuç}

Bu çalışmada ankete katılanların \%90'nı sütü sevdiklerini söylemesine rağmen düzensiz süt tüketimi olduğu anlaşılmaktadır. Araştırmaya katılan kırsal ve merkez ilce öğrencileri süt içme alışkanlıkları kırsal bölge kızlarda akşamları \%35, erkeklerde \%48 ( $\mathrm{p}=0,211)$; merkez bölge kızlarda \%55 ve erkeklerde ise ortalama $\% 59$ olarak tespit edilmiştir $(\mathrm{p}=0,282)$. Ankete katılan ailelerdeki çocukların $\% 20,62$ sı sicak \%23,5'u ise soğuk süt severken \%29,4’u meyveli süt içmeyi sevdiklerini belirtmişlerdir. Süt proteinlerinin büyümeye etkisi, doku farklılaşmalarındaki etkinliği yanı sıra; kalsiyum emilimi ve bağışıklık ve ayrıca diş sağlığ üzerine etkileri dikkate alındığında süt tüketiminin artırılması gerektiği anlaşılmaktadır.

\section{Kaynaklar}

Anar, Ş. (1998), Sütün Beslenmedeki Önemi. Gıda Dünyası, Haziran: 59-61

Anonyms, 2011. Türkiye'de Okul Çağı Çocuklarında (6-10 Yaş Grubu) Büyümenin İzlenmesi (Toçbi) Projesi Araştirma Raporu. http://www.istanbulsaglik. gov.tr/w/sb/ halksag/ belge/mevzuat/turkiye_okul_cocuk_6_10yas_buyume_izlen_rap.pdf

Anonim, 2011. Adana ili valiliği. http://www.adana.gov.tr/

22 | $\mathrm{P}$ a g e

www.iiste.org 
Ayçiçek A. Şanlıurfa ilindeki 0-8 yaş çocuklar için boy ve kilo referans değerleri. Çocuk Sağlı̆̆ ve Hastalıklar1 Dergisi 2005; 48: 234-238.

Cole TJ, Freeman JV, Preece MA. Body mass index reference curves for the UK, 1990. Arch Dis Child 1995; 73: 25-29. 6.

Demirci M, Yüksel A N, Soysal İ. Memeden Mamül Maddeye Süt. Hasad Yayınc1lı. Hayvancılık Serisi 1. İkinci Baskı. 1992, İstanbul, s: 103- 112

Göncü Karakök, S, Görgülü, M., 2008. Kaliteli Hayvansal ürün elde Edilmesinin Temel Koşulları. Hasad Dergisi, Eylül-Ekim, 2008, Yıl:24 Sayı281, 22-28s.

Göncü Karakök, S., Özkütük, K., Gökçe, G., 2007. Çukurova Bölgesi Sığır Yetiştiriciliğinin Yapısı ve Kaliteli Süt Üretiminde Yaşanan Problemler. Ç.Ü. Z.F Dergisi, 2006,21(4):21-30.

Göncü, S 2000. Adana Entansif Süt Sığırcılı̆̆ı İşletmelerinde Yetiştirilen Saf ve Melez Siyah Alaca İnek Sütlerinde Somatik Hücre Sayısına Etki Eden Faktörler ve Mastitis ile İlişkisi. Doktora Tezi. Adana.

Hammer LD, Kraemer HC, Wilson DM, Ritter PL, Dornbusch SM. Standardized percentile curves of body-mass index for children and adolescents. Am J Dis Child 1991; 145: 259-263. 5.

He Q, Albertson-Wikland K, Karlberg J. Populationbased body mass index reference values from Göteburg, Sweden: birth to 18 years of age. Acta Paediatr 2000; 89: 582-592

Karakaş S, Okyay P, Önen Ö, Ergin FA, Beşer E. Aydın ili kentsel ve kırsal bölge ilköğretim okulları 7-14 yaş grubu öğrencilerinin beden kitle indeksi. 8. Ulusal Halk Sağlığı Kongresi 2328 Eylül 2002, Diyarbakır: 741-744.

Kuczmarski RJ, Ogden CL, Grummer-Strawn LM, Flegal KM, Guo S, Wei R. CDC growth charts: United States. Adv Data 2000; 314: 1-27.27.

Ogden CJ, Kuczmarski RJ, Flegal KM et al. Centers for Disease Control and Prevention 2000 Growth Charts for the United ii:297-99. States: Improvements to the 1977 National Center for Health Statistics version. Pediatrics 2002; 109: 45-60.

Leung SS, Cole TJ, Tse LY, Lau JT. Body mass index reference curves for Chinese children. Ann Hum Biol 1998; 25: 169-174. 7.

Maijala K. 2000. Cow milk and human development and well-being. Livestock Production Science. 2000; 65: 1-18.

Neyzi O, Bundak R, Günöz, H. Darendeliler F, Saka N. 1996. Social class differences and secular trend in height in Turkish school chidren. In: Bodzsar BE, Susanne C (eds). Studies in Human Biology. Budapest: Eötvös Univ Press, 1996: 139-146.

Neyzi, O. , Günöz, H., Furman, A., Bundak, R., Gökçay, G., Darendeliler, F., Baş. F., 2008. Türk çocuklarında vücut ağırlığı, boy uzunluğu, baş çevresi ve vücut kitle indeksi referans değerleri. Çocuk Sağlığı ve Hastalıkları Dergisi, 2008; 51:-14.

Ogden CJ, Kuczmarski RJ, Flegal KM. 2002.Centers for Disease Control and Prevention 2000 Growth Charts for the United ii:297-99. States: Improvements to the 1977 National Center for Health Statistics version. Pediatrics 2002; 109: 45-60.

Onat T, Ertem B. 1995. Age at menarche: relationship to economic status, growth rate in status and weight, and skeletal and sexual maturation. Am J Human Biol 1995; 7: 741-750. 22. 
Onurlubaş E, Çakırlar H (2016).Tüketicilerin Süt ve Süt Ürünleri Tüketimini Etkileyen Faktörlerin Belirlenmesi Üzerine Bir Araştırma, Çankırı Karatekin Üniversitesi Sosyal Bilimler Enstitüsü Dergisi, 7(1): 217-242.

Özkütük K, Göncü S. 1996. Sicaklık stresinin süt sığırcılığı ve besi üzerine etkisi konusunda Çukurova Bölgesi'nde yapılan çalışmalar. Hayvancılık'96 Ulusal Kongresi, Türkiye, 18 - 20 Eylül 1996, cilt.1, ss.37-44

Rosner B, Prineas B, Loggie J, Daniels SR. Percentiles for body mass index in U.S. children 5 to 17 years of age. J Pediatr 1998; 132: 211-22

Sarria A, Moreno LA, Garcia-Llop LA, Fleta J, Morellon MP, Bueno M. Body mass index, triceps skinfold and waist circumference in screening for adiposity in male children and adolescents. Acta Paediatr 2001; 90: 387-392.

SPSS (2004). SPSS for windows Release 13.0. SPSS Inc., Chicago, IL.

TUIK; 2021.TÜIKK Hayvansal Üretim İstatistikleri. https://data.tuik.gov.tr/ Bulten/ Index?p= Hayvansal-Uretim-Istatistikleri-Haziran-2020-33874

World Health Organization (WHO), 2006. Multicentre Growth Reference Study Group. WHO Child Growth Standards based on length/height, weight and age. Acta Paediatr 2006; 450 (Suppl): 76-85. 